\title{
Human Resource Accounting and Quality of Financial Reporting of Quoted Oil and Gas Companies in Nigeria
}

\author{
Akinlade Olayinka Odunayo, Adegbie Folajimi Festus \\ Department of Accounting, Babcock University, Ilishan-Remo, Nigeria \\ Email address: \\ akinladeolayinka2018@yahoo.com (A. O. Odunayo), adegbief@babcock.edu.ng (A. F. Festus)
}

\section{To cite this article:}

Akinlade Olayinka Odunayo, Adegbie Folajimi Festus. Human Resource Accounting and Quality of Financial Reporting of Quoted Oil and Gas Companies in Nigeria. International Journal of Accounting, Finance and Risk Management. Vol. 5, No. 4, 2020, pp. $195-206$. doi: 10.11648/j.jjafrm.20200504.14

Received: September 26, 2020; Accepted: October 22, 2020; Published: December 8, 2020

\begin{abstract}
Financial reporting is a veritable tool that provides information to all stakeholder's for the purpose of decision making. The preparation and presentation of the report is done by the human asset. Building public confidence for capital market participants, transparency, and trust are very germane in any capital market. Poor earnings quality, opportunistic earnings and biased financial report portents great fears in the mind of investors and analysts alike in making rational investment decisions. The study investigated the effect of human resource accounting on quality of financial reporting (using earnings quality, accounting conservatism, earnings smoothness and persistence as proxies) of quoted oil and gas companies in Nigeria. The study adopted ex-post facto research design. The population of the study was 12 oil and gas companies in Nigeria. Purposive sampling technique was used and considered 12 oil and gas which had secondary data information that covered a period of 10 years from $2004-2018$. The null hypothesis $\left(\mathrm{H}_{0}\right)$ : Human Resource Accounting does not have significant effect on financial reporting quality in oil and gas companies in Nigeria The empirical findings of financial reporting quality revealed that the human asset provided the basis for these improvement in oil and gas companies with the results $F_{(8.133)}=65.13(P-$ value $=0.000)$; Adjusted $R^{2}=0.315$ and $F_{(5.102)}=217.6(P-$ Value $=0.000)$; Adjusted $R^{2}=0.323$. The study concluded that human resource accounting has significant effect on financial reporting quality of quoted oil and gas companies in Nigeria. The study recommended that the regulatory bodies should find ways of rewarding companies that comply with the regulatory guiding standards and comply with information disclosure for earnings quality assessment and sanction erring companies that conceal relevant and purposeful information from the stakeholders.
\end{abstract}

Keywords: Financial Report, Financial Reporting Quality, Human Resource Accounting, Oil and Gas Company, Public Confidence, Regulatory Body

\section{Introduction}

Accounting continues to develop as human civilization improves overtime (such as: [1]). The achievement of advancement in concepts and applications cut across all human endeavors including accounting. "According to [14], accounting is the bedrock for information infrastructure used by managers and their stakeholders to achieve various economic decisions". This implies that accounting is an information system that aids effective communication and decision making. Corporate organization sees accounting as a variable tool of communicating to users of financial statement about their financial performance, financial position and cash flows of a business entity during a specific period (such as: [2]). The process through which companies communicate to the public about their operations or activities is called financial reporting. Corporate financial reporting is the medium through which companies disseminate information to the public about their operational performance in terms of profitability, efficiency and responsibility (such as: [37]).

Financial reporting of a corporate entity constitutes a combination of qualitative and quantitative financial reports, which are referred to as a company's bill of health. "According to [6], various stakeholders take their decisions relative to a company's performance and position based on the information supplied by it in its annual financial reports and accounts". These financial statements are required to 
exhibit certain degree of quality in terms of their information contents. [27] opined that information contained in the financial reports should possess certain qualities as relevance, verifiability, understandability, neutrality, timeliness, comparability, and completeness through which the stakeholders could make decision. "According to [9], stakeholders rely on the quality of financial statements disclosure".

The growing importance of human capital in all sectors of economy led to the new direction in knowledge based economy especially in oil and gas sector. Currently life is tending towards the intangible economy where knowledge of economics is the new reality (such as: [1]). Researchers have moved to assessments of the stock of intellectual capital at the national level which signifies an intellectually based economy that is characterized among other things, by a defiance of the long standing economics law of diminishing returns (such as: [1]) where the power of increasing returns for knowledge gained is the order of the day. In other words, the increase in knowledge can be subjected to the law of diminishing return with time and usage, renewable from time to time, growing stronger with sharing and exchange (such as: [3]).

Akintoye [3] opined that the development of human resource accounting originated from the growing needs of the importance of human asset in the management of organization. It functions as a department that monitors the people that are involved in the organizational resources, as well as monitoring the development, progress in assets and revenues of the company (such as: [7]). "According to [16], the inclusion of human asset has become essential in the financial reporting because of its contribution to the attainment of the organizations goal". In today's business environment, companies need to make use every advantage available to remain competitive. Global competition, rapid innovation entrepreneurial competitors and increasingly demanding customers have altered the nature of competitions in the market place.

The human asset is use by companies to provide financial information about financial performance measure in terms of earnings. This became a basis for decision making for stake holders. Unfortunately human asset is not capitalized but rather expensed in spite of it immense contribution to the business success (such as: [13]). "According to [15], customers, employees, government agencies, shareholders and investors among others, each contribute to the operation of the firm in which they have relationship with". Such relationship created different degree of services to management which they exhibit by providing certain level of incentives in monetary, physical, economic or social depending on each category of beneficiary that was reported to them in the financial statement prepared by the human asset in the organization (such as: [40]). Therefore, human resource accounting has been of paramount importance which demonstrates that it has significant effect or relationship with quality of financial reporting for different stakeholders (such as: [32]).

Akintoye [3] stated that human asset was discovered to be one of the most critical signals to corporate performance as against historical Jargons / models currently littered on the pages of financial statement backed up a supposed letter of comfort (Auditors report) which are usually discomforting investors from past unwholesome experience and loss of financial fortune. This raised many question related to the quality of and relevance of the reports prepared and published by corporate entities especially the oil \& gas listed companies in Nigeria.

Human resource is adjudged as the catalyst for the transformation of the global economies from informationbased to knowledge-based (such as: [32]). In the information and knowledge based economies, human brain and intellectual abilities and capabilities are the key ingredients. However, the accounting aspect of the human capital is yet to be fully accepted and applied in the corporate financial reports of corporate entities. This raised many questions relative to the quality and relevance of the reports prepared and published by corporate entities especially the oil $\&$ gas companies in Nigeria.

The justification for the study is that there are limited number of studies on human resource accounting and financial reporting in public quoted oil \&gas companies in Nigeria (suh as: [4]). In this sector, there is a need for research to be carried out in order to assess the significance effect of human resource accounting on quality of financial reporting in Nigeria. The study provided empirical findings about the value that human asset brings to the organisation that is expressed through the financial reporting quality of quoted oil \& Gas Companies in Nigeria.

While other studies considered only qualitative characteristics of financial information and human resource accounting (such as: [10]) while others used financial reporting quality (quantitative measures), IFRS adoption, information disclosure and performance of firms or corporate governance (such as: [41]). This study on the other hand combined both quantitative and qualitative measures in evaluating effect of human resource accounting and the quality of financial reporting in quoted oil \& gas companies in Nigeria. Furthermore, most of the previous studies that were conducted in the area of financial reporting and human resource accounting were from the other sectors in the developed economies, and other developing nations with limited studies in the oil \& gas sector of the economy. Hence the study is on the quoted oil \& gas companies in Nigeria.

The main objective of this research is to evaluate the effect of Human Resource Accounting on the quality of Financial Reporting (earnings quality, accounting conservatism, earnings smoothness and earnings persistence) in quoted oil and gas companies in Nigeria.

\section{Literature Review / Theoretical Framework}

\subsection{Conceptual Review}

The aim of quality of financial reporting is to promote 
transparency and deliver high quality annual report through the contribution of human assets in an organization. It sets the state of the art as far as the concepts of Human Resource Accounting (HRA) and quality financial reporting are concerned. Literatures relevant and related to the field of HRA and quality financial reports are reviewed for the purpose of bringing the research into a proper perspective (such as: [6]).

\subsubsection{Financial Reporting Quality}

Financial reporting involved recording financial information according to relevant accounting standards. "According to [15], financial reporting quality includes the exposure of related financial information to the different Stakeholders about an organization over a pre-defined timeframe. These Stakeholders include - investors, lenders, suppliers, and government organizations". "According to [12], financial reporting is considered as the final result of Accounting". It comprises of various important statements which include - financial related explanations from Statement of financial position, Statement of comprehensive income, Statement of cash flow, Statement of changes in equity, notes to financial related explanations, Quarterly and Annual reports (if there should be an occurrence of quoted organizations), Prospectus (if there should be an occurrence of organizations going for Initial Public Offers) and Management Discussion and Analysis (if there should be an occurrence of open organizations).

\subsubsection{Earnings Quality}

Earning quality is the ability of the company to provide potential framework of growth of earnings and its perpetual realization (such as: [18]). It is clear that based on theory of value that amount invested in one share is supposed to earn and generate return which is earning per share as per today and show the prosperous expectations of future earning generation capacity (such as: [19]). Thus, the value of a share bought by investors or value of debentures purchased by bondholders is assumed to provide earnings per share bond and is dependent on company's earning capacity to continually provide and secure future dependable earnings (such as: [21]). Thus, it is earning quality of entity that determines its financial position and performance, now and in future, that is secured if the company has a vision and mission of generating earnings currently and determining if there is a clear possibility of continually generating earnings in the future periods of time (such as: [28]).

"According to [36], the measurements of earnings quality in portfolios management required the estimations of high and very lower values of earnings and then proceed to the computation of the difference that may exist in the absolute returns of a company'. When there is a huge difference it becomes a positive indicator of good earnings measurement (such as: [20]). The data that used, are collected from time series of a number of years which help in measuring the persistence of earnings or otherwise (such as: [34]). It further predictability of future earnings, smoothness measurements also are applied and accruals measurements then as theory of value assumes it will be useful to apply value relevance measurements of earnings quality and investors will base their decision on persistence and predict ability than smoothness which support earnings management (such as: [9]).

Abubakar [1] considered that earnings quality measured by financial reporting quality, capital markets incentives, governance and control systems, quality of auditors opinion, external factors and strategies guides firm's operations and is important for all stakeholders value creation especially, investors. [9] posited that low earnings quality has significant positive effect on higher performance of listed companies.

\subsubsection{Accounting Conservatism}

The accounting conservatism referred to the maximum degree of approving and verifying the legitimacy of any financial information to be included in financial statements and is used for the transactions that require the recognition of probability in terms of profits or losses at the reporting period (such as: [5]). This provides relevant alternatives between many options (such as: [4]). Thus it helped to get fair and objective financial statements and avoided financial information that can mislead users (such as: [38]). Accounting conservatism is not a new concept in accounting and theory of value. It is generally posited that managers of companies needed to be selfish in the application of accounting techniques beneficial to themselves and this is referred to as agency problems and costs (such as: [18]). Thus, accounting conservatism is one of the means that helps to reduce the agency problem in such a way that it leads to better firms 'performance especially in capital markets. It is this perspective that investigated the effects of accounting conservatism in respect to theory of human capital development.

Accounting conservatism is a tool for addressing the issue of agency costs and provided clearer and effective information to decision makers who need to get evidence about the future events that will affect company's financial position and financial performance (such as: [22]). Since there was clear separation between shareholders and mangers of companies, there was perception on the issue of agency problems where managers cheated other party by selecting accounting practices that were beneficial to them and disfavor stockholders and managers reported unfairly to stakeholders (such as: [1]). [20] posited that the use of accounting conservatism mitigated the existence of such issue and did not allow managers to overstate financial position and earning of the company because accounting conservatism taught and recommended the use of formal accounting- based contracts to mitigate managers overstatements of self - interest. Larsson and Morling [18] documented that the use of accounting conservatism added value to the financial reporting framework with main objective of reduction financial statements manipulated by managers.

\subsubsection{Earnings Smoothness}

Earnings smoothness is the capacity of a company to communicate financial information about the future cash flows and earnings capacity in the future periods of 
accounting. Earnings are used in measuring a company's cash flows (such as: [21]). It is in this perspective that accrual accounting quality explains the accounting reporting quality in such a way that based on current earning capacity, managers and other decision makers are able estimate or predict future cash flows and performance with more clear emphasizes on working capital capacity are more evidence of future operating capacity (such as: [22]).

Earnings smoothness also helps managers to make a kind of forecast which is an action of management discretion in planning the future cash flows and earnings. It is recognized as a tool for getting reliability future plans that is based on the current business environment (such as: [19]). Earnings smoothness leads to the planning of value of future cash flows in persistent manner and investors rely on it as they anticipate the future cash flow and earnings of the company in which need to invest their capital and generally investors and other capital market based their ideal and investment decision based on this method of accrual accounting quality (such as: [19]). Also go beyond the number sand figures including financial statement but also on current and future tendencies of the business environment, political status of the country where they want to invest their resources, and factors of productions costs (such as: [29]).

Abubakar [1] indicated that earnings smoothness is important because it helps in drawing inferences that regard earnings quality of the company and accruals quality posited that financial reporting quality in China make use of earning smoothing. Accrual quality is also used to manage firm earnings which are not recognized on time in terms of loss recognition. Abubakar [1] demonstrated that earnings quality and smoothness are used in financial investment and this shows that the listed companies are placed on capital market and capital acquisition and non-listed companies still have accounting deficiencies regarding financial reporting quality.

\subsubsection{Earning Persistence}

The purpose financial statement is to provide financial information useful for investor's decision making (such as: [39]). According to [23], the financial statements provide useful information to assess the company's performance and predict the return on investment or resources to be allocated to the company. With financial statement information, investors can assess the company's ability to generate profits and expect a return on its investment. Several studies have shown a relationship of earnings management with market reaction. Market reaction can be measured using earnings response coefficient (ERC). [18] believed that accrual quality showed a negative relationship between earnings management and ERC. Earnings management is a negative signal for investors, because market participants view that earnings management will reduce the quality of earnings. The company's earnings do not show real financial performance. Companies with higher revenues will be vulnerable to earnings management. Research conducted by [40] showed that companies that reported sustained revenue and earnings, have high earnings quality and the level of earnings response coefficients than companies that reported sustained revenue only. Earnings management and earnings persistence are factors related earnings response coefficient. Investors will assess the quality of accounting profit generated by management in managing the company. Management contracted the owner to manage the company, and aims to increase the prosperity of the owner. At some point, there will be a conflict of interest between management and owners. Management has access to more information while the owner otherwise causing asymmetry of information (such as: [33]).

\subsubsection{Human Resource Accounting (HRA)}

Human resource (HR) is a term used to describe the individuals who comprise the workforce of an organization, although it is also applied in labour economics to business sectors or even whole nations (such as: [21]).

Human resources is a relatively modern management term, coined as scientific management' (such as: [35]). From these terms emerged a largely administrative management activity, early as the 1960 s - when humanity took a shift as human rights came to a brighter light during the Vietnam era (such as: [26]).

HRA considers human resource as equivalent to other assets in the organization and they require investment over time to make them productive. Such investment relates to the hiring, training, and development costs, which are capitalized and amortised over an assumed probably productive life for the human resource, taking into account attrition and eventual deterioration (such as: [12]). The concept of HRA has been defined in so many ways but the basic feature of the system remains the same in every definition.

HRA was also seen as an important aspect of management information system. In this view, [14] defined the concept as basically an information system that tells management what changes are occurring overtime to the human resource of the business. It involved accounting for investment in people and their replacement costs, and also the economic value of people in an organization. This definition regarded HRA as an information system capable of assisting the management in effective decision-making relative to the hiring and retention of employees. Therefore, HRA provided a comprehensive look at one method of using human resource cost and value information in the decision-making process (such as: [4]).

\subsubsection{Wages and Salary Benefits}

Wages and salary benefits can be likened to return to investments accrued to individuals as a result of invested expertise, technical provision, time and energy put into achievement of an organizational goals. Wages and fringe benefits Wages and other conditions of employment in the Organized Private Sector (OPS), including the oil sector, are determined by collective bargaining between unions and employers or employers' associations. A national minimum wage, determined by the National Assembly, must be observed by every enterprise employing more than 50 workers. The actual minimum paid may be higher - both in public employment and, more markedly, in the OPS - except in the 
case of casual workers. General wage and salary increases in the public sector are decided by the federal Government. These inevitably result in employers in the private sector being subjected to union pressure to award increases as well, including in the oil sector by most of them because they need cash. When remuneration was provided in kind, workers did not feel that they were benefiting from it. Hence, the introduction of cash is a welcome development.

\subsection{Theoretical Review}

The study reviewed two theories which were:

I. Stakeholders Theory.

II. Human Capital Theory.

\subsubsection{Stakeholder Theory}

The proponent of the theory R. Edward Freeman laid emphasy on stakeholder survival in the organization. "According to Watson [12], the stakeholder theory emphasizes that some individual or group is very important for the survival of the organization". This explanation is seen as organization oriented explanation, but in an earlier research freeman reported that stakeholder theory refers to any group or individual who can affect or who is likely to be affected by the achievement of the organization objective.

Klai [17] criticized the theory by making reference to the financial crisis that characterized $20^{\text {th }}$ century, the criticism is that shareholder theory focuses only on owners of capital value and it does not consider other shareholders interest such as social value, employee value, an environmental value creation. This theory emphasizes on shareholder's value maximization and minimizing other shareholders interest (third parties).

Mehdi et al. [25] opined that this theory lowers the economic growth rate by reducing capital circulation, This is explained for instances by the view of maximizing shareholders interest by reducing other partners interest such as selling products or services of low quality at lower prices. This theory also is detrimental on searching short term profit for shareholders by not considering the long term value creation for the same shareholders.

Higson [15] posited that shareholders value maximization is detrimental for the business worth. They show that managers usually focus on increasing shareholders value where share pieces are mostly privileged; as a result the ethical values are disregarded and sacrificed because of shareholder's interests. Jarostia [16] demonstrated that this theory also lack transparency, due to the fact that firms share value is based on the profit that has been generated in certain accounting year. The main focus of the firm is to generate more profit even more than they expected value, the pursuit of this goal makes it difficult to do fair businesses and there is intention even to engage in fraudulent activities, where managers present unfair report and try to show a wrong picture of their finances and as a result reporting becomes inconsistent and lack transparency where only managers know the real profit earned than even employees do not know (such as: [14]).

Bhatti and Zaheer [8] posited that shareholders value pursuit leads to acquisition of the businesses risk, where managers accumulate the debts without financial capacity, and as a result put themselves at bankruptcy of the entire business. Shareholders value pursuit focuses on short term and ignores the long term sustainability of the business, because owners of capital needs to receive dividends on annual basis than using part of earnings in business expansion. [18] reported that stakeholders theory emphasized that all stakeholders have right to be provided with relevant information about how the organization and this information could involve information about influence of pollution from the organization to the environment, information about community sponsorship, information on provision of employment, information on safety initiative provided by the organization.

\subsubsection{Human Capital Theory}

This study was based on the Human Capital theory proposed by Schultz and extensively developed by Becker. The theory has its root from labour economics which is a branch of economics that focuses on general work force in quantitative term. "According to the theory, Human capital theory contends that education or training raises the productivity of workers by imparting useful knowledge and skills, thus raising workers' future income through increase in their lifetime earnings". The theory postulates that expenditure on education or training and development is costly, and should be considered as investment since it is undertaken with a view to increasing personal incomes. Human capital approach is used to explain or support occupational wage differential (such as: [26]). However, the position of this study is that education or training and development will not only increase employee personal income, it will also serve as a means of achieving corporate competitive advantage which ultimately reflects in organizational performance. According to Higson [15], as noted by Klai [17], human capital theory distinguished between general skills and firms' specific skills of human resources. General skills are skills possessed by individuals which provide value to a firm and are transferable across a variety of firms. For instance, all competitor firms have the potential to accrue equal value by acquiring employees with knowledge of general management, the ability to apply financial ratios, or general cognitive ability. On the other hand, specific skills provide value only to a particular firm, and such skills are of no value to competing firms. An instance of this is the knowledge of how to use a particular technology used only by one firm, or knowledge of a firm's policies and procedures provided to that firm, but usually would not be valuable to other firms (such as: [19]).

\subsection{Empirical Review}

"According to Higson [15], the quality of financial reporting include completeness as other characteristics of useful accounting information and should be given a total picture of the reporting business entity as far as possible". Mehdi et al. [25] posited that the quality of completeness 
ensures that users are given a round picture of the economic activities of the firm (such as: [28]).

Eke [11] stated that corporate entities need to build capacity to drive the process and revisit their operational and internal control systems. More so, the laws need to be amended and the transition processes need to be handled efficiently, effectively and professionally in order to sustain the confidence of users of accounting services on the confidence of users of accounting services on the skills of professional accountants (such as: [5]).

Martinez [24] stated that the successful adoption of IFRS entails assessing technical accounting, tax implications, internal processes, and statutory reporting, technology infrastructure, and organizational issues. Due to the markets and business globalization, geographical expansion and the greater demand for information and transparency among investors, stakeholders and society in general, market agents find their toehold in the quality of their financial reporting and their main source of knowledge on company strategy. "According to Pivac et al. [33], financial reporting is not only a final output; the quality of this process depends on each part, including disclosure of the company's transactions, information about the selection and application of accounting policies and knowledge of the judgments made". Financial information issued by a company has become an essential resource for any market participant, since it provides a reduced amount of information asymmetries between managers, investors, regulatory agencies, society and other stakeholders. Therefore, one of the main questions that arise about the quality of financial reporting is its effect on subsequent performance of a company, i.e. how the market values this higher perceived quality (such as: [38]).

Human resource constitutes a valuable resource to every organization in the world. It is as important as the machines, materials and money without whom other resources cannot be blended and coordinated for the purpose of achieving profitability (such as: [31]). Characteristics such as experience, skill, knowledge, and age affect the productivity of human resource. Reporting information on the value of a company's human resource via the use of a standard and realistic model could add value to the information content of financial reports of organizations and hence assist users in making informed decisions (such as: [30]). In addition, [39] pointed out that the information generated by HRA systems can be put to use for taking a variety of managerial decisions. The advancement of societies and the gradual transformation to knowledge-based societies requires the unfreezing of certain processes and procedures including such relating to management, accounting and finance (such as: [37])

In a study carried out by [31] titled "regulation of financial reporting for accountability in public companies in Nigeria, sought to correlate the non-compliance with the financial standards and governance code in 20 selected public quoted companies on the Nigerian stock exchange (NSE) in the Delta State. The population of the study was made up of 20 public companies quoted on NSE. The instrument for data collection was questionnaire. Data collected was analyzed using percentages and chi - square. The study revealed that there is a general problem of accurate financial reporting of accounts of some public companies which resulted in misleading of the prospective investors and the general public at large. The authors recommend that stipulated penalties go to deviants as to enforce a credible reporting system.

In another study carried out by Paoloni, Paolucci and Menicucci titled "The role of behavioral accounting for effective service delivery in corporate accounts of public companies" sought to ascertain the effect of corruption on corporate accounts and behavioral accounting as a measure to achieving public objective. It was found that behavioral accounting recognizes the extent to which internal and external influences in the course of operating the system of accounting changes corporate objectives of the organization.

\section{Methodology}

The expost facto research design was adopted in the study of the relationship between dependent and the independent variables which are Quality of Financial Reporrtingand Human Resource Accounting repectively. Also, the study adopted panel regression in analysing 12 public quoted oil and gas companies in Nigeria for the period of 10 years from 2009-2018. The adoption of the design was because the study involved the measurement of different variables in the assessment of the extent of the relationships. The design was used by Adelaja on empirical analysis of human capital development and relationship with the financial statement. Also, for the study by Cheng on the significance of human resource accounting and the financial report of quoted oil and gas companies in China. The design was used because the research cuts across various companies and years. Hence, the panel data research design was adopted.

The Study employed the use of descriptive statistics to help in the analysis of the impact of human resource accounting variables on each component of financial reporting quality, and they also produced empirical results that formed the basis for decision model. The inferential statisticsused was multiple regression analysis where ordinary Least Square was used to test the null hypothesis qualititavely that were set in this study. This was based on the fact that OLS regression analysis is the best statistical tool that helps researcher to measure the level of the effect of the independent variable to dependent variable.

For panel data there were use of static panel models for testing the quantitative models and used quantitative meaasures of human resource accountingt on each of the dependent varaibles represented by quantitative measures. They were tested at $1 \%, 5 \%$ and $10 \%$ anticipated degree of error. Thus, the rule is that each probability value of the independent variable will be compared with the critical pvalues $0.01 ; 0.05$ and 0.10 . Where if $\mathrm{p}<0.01 ; 0.05$ and 0.10 ; the effectis statiscally significant and the null hypothesis will be rejected, and if $p>0.01 ; 0.05$ and 0.10 the effects is not statistically significant and the null hypothesis will 
beaccepted for hypotheses. The results were generated using stata version 14 where pooled OLS, Fixed Effect, Random Effect and Discroll- Kraay Standard Error models were used. This was done after the analysis of descriptive statistics for human resource accounting and quality of financial report variables and the pre estimation test where pearson pairwise correlation was used

Again Unobserved Effects Model (UFM) was used because of the use of panel regression model, and since the secondary data derived from many quoted oil and gas companies in Nigeria. The UEM indicated either fixed effects or random effect depends on the assumptions about distribution of unobserved components and the error term, with stochastic process of the time series across company (that is, the unit root procedures), and the asymptotic properties of the year $(\mathrm{t})$ and company (i). The reason of choosing the UEM was based on the fact that the resullt of the Hausman test and other test were performed with the underlining assumptions of multiple regression at $\mathrm{p}$-value of $0.01 ; 0.05$ and 0.10 .

\section{Results and Discussion of Findings}

The summary of the Human Resource Accounting indicators (Wages and Salaries (WAS), Pension and Retirement Benefits (PRB) and Number of Employees (NE) as well as the control variable (Firm Leverage (LEV)) and quality of financial reporting indicators (Earnings Quality (EQT), Account Conservatism (ACC), Earnings Smoothness (ES) and Earning Persistence (EP)) are presented in the Table below.

HO: human resource accounting does not have significant effect on financial reporting quality in oil and gas companies in Nigeria.

Table 1. Summary of Variables.

\begin{tabular}{|c|c|c|c|c|c|}
\hline Variable & Obs & Mean & Std. Dev. & Min & Max \\
\hline \multicolumn{6}{|c|}{ Dependent Variables } \\
\hline EQT & 90 & 0.133 & 0.124 & 0.007 & 0.629 \\
\hline $\mathrm{ACC}$ & 90 & 1.199 & 1.517 & 0.008 & 8.997 \\
\hline ES & 90 & 0.872 & 1.188 & 0.060 & 8.808 \\
\hline EP & 90 & 0.056 & 0.813 & -4.056 & 2.773 \\
\hline \multicolumn{6}{|c|}{ Independent Variables } \\
\hline WAS (N'Million) & 90 & 2133.16 & 2462.59 & 0.62 & 12004.33 \\
\hline NEMP & 90 & 230.46 & 181.87 & 20.00 & 605.00 \\
\hline LEV & 90 & 0.717 & 0.257 & 0.105 & 2.006 \\
\hline
\end{tabular}

Source: Authors Computation, 2020.

From the results in Table 1, considering the Earnings Quality; it has an average value of 0.133 which can be interpreted as $13.3 \%$. The result shows that the minimum and maximum values are 0.007 and 0.629 respectively; with standard deviation being 0.124 , which are evidences of relatively wide variation in the series, even as being shown by the differences between the minimum and maximum values. Observation number is 90 . The average of another dependent variable which is Accounting conservatism (ACC) for all the companies is 1.199 , which means the average value of an essential feature of Earning quality is 1.199. However, the standard deviation stands at 1.517, as can be seen in the differences that exist between the highest and the lowest values 8.997 and 0.008 respectively, which depicts that, there exist wide range of dispersion in Accounting Conservatism (ACC), with number of observation taken into consideration being 90 . The result also shows that during the particular years of study, the companies on average maintained Earnings Smoothness (ES) of 0.87; the minimum and maximum values of Earnings smoothness are 0.060 and 8.808 respectively with standard deviation of 1.188 under observation number being 90. The Earnings Persistence (EP) which is an income that continues from one year to the next, often affected by the magnitude of the accruals; in other words, its what determines whether or not earnings of company are expected to recur or not: it has mean value of 0.056 with standard deviation of 0.813 .
Based on the independent variables in which one of them is Wages and Salaries expressed in Naira Million having its minimum and maximum values as N0.62million and N12, 004.33 million respectively, with a very wide range of variations as can be seen in the standard deviation which is 2462.59. Similarly, Pension and Retirement Benefits (PRB) which is also expressed in Naira Million, has mean value of N188.23million with spreading-out value or dispersion value of 222.95. Also, Number of Employees (NEMP) is having an average value 230.46 and standard deviation value of 181.87 , with lowest and its highest values being 20.00 and 605.00 respectively. These mean that on average the firms have employed 230 workers with the range of 20 to 605 workers. Furthermore, the firm characteristics variable called Firm Leverage (LEV), has an average value of 0.717 which indicates that the firms on average financed about $71.7 \%$ of asset on borrowing. This independent variable takes values between 0.105 and 2.006 with standard deviation of 0.257 .

\subsection{Correlation Matrix}

This particular section presents the preliminary correlation analyses results among both dependent variables and independent variables. The results serve two germane purposes; in which the first is to determine whether there exist bivariate relationship between each pair of both dependent and independent variables discussed in this study. And the second important purpose is to ensure that the 
correlations among the explanatory variables not so great to the point of posing multi-colinearity problems.

Table 2. Correlation Matrix.

\begin{tabular}{lllllllll}
\hline & EQT & ACC & ES & EP & WAS & PRB & NE & LEV \\
\hline EQT & 1 & & & & & & & \\
ACC & -0.225 & 1 & & & & & & \\
ES & -0.367 & 0.311 & 1 & 0.436 & 1 & & & \\
EP & -0.174 & 0.234 & -0.056 & -0.122 & 0.245 & 1 & & \\
WAS & -0.184 & -0.414 & 0.004 & 0.005 & 0.063 & 0.543 & 1 & \\
PRB & -0.129 & 0.099 & 0.036 & 0.111 & 0.646 & 0.366 & 1 \\
NE & -0.035 & 0.227 & 0.122 & 0.109 & 0.254 & 0.207 & 0.094 & 1 \\
LEV &
\end{tabular}

Source: Authors Computation, 2020.

It's seen from Table 2 that there is no evidence of multicollinearity among the independent variables considered, seeing that the correlations or relationships among the independent variables are not generally strong. Specifically, the result shows that there exist negative correlation $(\mathrm{r}=$ 0.225 ) between EQT and ACC; and its also negatively and insignificantly correlated to other variables. For ACC, there exist positive correlation with all variables aside WAS which is negatively associated with it. All correlation coefficients for ES are $0.436,-0.122,0.005,0.036$ and 0.122 with EP, WAS, PRB, NE and LEV respectively. Also, EP is positively correlated with WAS $(\mathrm{r}=0.245)$, PRB $(\mathrm{r}=0.063), \mathrm{NE}(\mathrm{r}=0.111)$ and LEV ( $\mathrm{r}=0.109)$. The association between PRB with NE and LEV are positive, so also association between NE and LEV ( $r=0.094)$. Even though the correlation coefficients of PRB, NE and WAS appear to be high these do not mean that multi-collinearity exists. To confirm this declaration we proceed to Variance Inflation Factor (VIF).

\subsubsection{Variance Inflation Factor}

As noted earlier, the result presented in Table 3 shows the VIF of variables considered in this study for multicollinearity test. According to various numbers of authors, they emphasized that a VIF with the value below 5 and a tolerance value that is approaching lindicate no harmful effect of multi-collinearity.

Table 3. Variance Inflation Factor.

\begin{tabular}{llc}
\hline Variable & VIF & \multicolumn{1}{c}{ 1/VIF } \\
\hline & \multicolumn{1}{l}{ Model without Control Variable } \\
WAS & 2.11 & 0.474 \\
NE & 1.72 & 0.582 \\
PRB & 1.42 & 0.705 \\
Mean VIF & 1.75 & \\
& Model with Control Variable \\
WAS & 2.19 & 0.456 \\
NE & 1.73 & 0.577 \\
PRB & 1.43 & 0.700 \\
LEV & 1.09 & 0.920 \\
Mean VIF & 1.61 & \\
\hline
\end{tabular}

Source: Authors Computation, 2020.

Based on the result in Table 3, the mean VIF values are 1.75 (for model without Control Variable which constitutes WAS, NE and PRB) and 1.61 (for model with Control variable which constitutes WAS, NE, PRB and LEV) which are greatly less than 5 (the value given by numerous authors). In panel A; WAS, NE, and PRB have VIF values of 2.11, 1.72 and 1.42 respectively, while in panel B, WAS, NE, PRB and LEV have VIF values of 2.19, 1.73, 1.43 and 1.09 respectively. It can be seen also that corresponding reciprocal of tolerance for both panels are a bit close to 1 ; this is an indication that the variables under consideration are not perfect linear combination of each other.

\subsubsection{Regression Analysis}

In order to achieve the objective of this study and test the hypotheses stated, Presentation and discussion on the estimates of the regression analysis carried out in this subsection are made. Four (4) regression models were estimated as base models as noted in the preceding chapter. The first model examines the relationship between Human Resource Accounting indicators (Wages and Salaries (WAS), Pension and Retirement Benefits (PRB) and Number of Employees (NE)) and Earnings Quality (EQT). The second model investigates the relationship between Human Resource Accounting indicators (Wages and Salaries (WAS), Pension and Retirement Benefits (PRB) and Number of Employees (NE)) and Account Conservatism (ACC). The third is concerned about the relationship between the selected Human Resource Accounting indicators and Earnings Smoothness (ES). In addition to these, the fourth model is the model that studies the relationship between Human Resource Accounting indicators and Earning Persistence (EP).

Furthermore, to examine the moderating effect of leverage on the relationship between Human Resource Accounting indicators and financial reporting quality poxied by Earnings Quality (EQT), Account Conservatism (ACC), Earnings Smoothness (ES) and Earning Persistence (EP). The starting model is pooled (OLS) regression model.

\subsubsection{Hausman and Breusch and Pagan LM}

In static panel regression framework, the Breusch and Pagan Lagrangian multiplier test for random effects is usually carried out to check whether panel effect is present or not. To begin with, a simple model which is also known as Pooled regression model. This model is also known as OLS. This is because the model serves as the origin of any other type of regression model. The use of Fixed or Random effect model is based on the assumption that panel effect exists because we are concerned with combination of cross-section 
and time series data. However, to choose the most appropriate model among the three panel estimators which includes; Pooled, Fixed and Random models LM test is used. For LM test the null hypothesis is 'variance across entities is zero'. In other words, it means there is no panel effect. Furthermore, if the null hypothesis of zero variance across entities is rejected, then we move to Hausman test which can reliably show a useful model between Random Effect Model and Fixed Effect Model. This approach fundamentally tests whether the unique errors are correlated with the explanatory variables; the null hypothesis is they are not. Using this test, Random Effect model is preferred if the null hypothesis is accepted. In other words, rejection of the null hypothesis indicates that Random Effect Model is not appropriate but fixed.

Table 4. Hausman and Breusch and Pagan Lagrangian Multiplier Tests.

\begin{tabular}{|c|c|c|c|c|}
\hline Dependent & Independent & & Hausman Test [P-value] & LM Test [P - value] \\
\hline \multirow{2}{*}{ Earnings Quality } & & $-\mathrm{CV}$ & $25.72[0.000]$ & $37.70[0.000]$ \\
\hline & & $+\mathrm{CV}$ & $18.86[0.001]$ & $37.95[0.000]$ \\
\hline \multirow{2}{*}{ Account Conservatism } & & $-\mathrm{CV}$ & $11.65[0.009]$ & $73.19[0.000]$ \\
\hline & Human Resource & $+\mathrm{CV}$ & $16.17[0.003]$ & $86.82[0.000]$ \\
\hline \multirow{2}{*}{ Earnings Smoothness } & Accounting & $-\mathrm{CV}$ & $16.91[0.000]$ & $19.35[0.000]$ \\
\hline & & $+\mathrm{CV}$ & $16.79[0.002]$ & $20.24[0.000]$ \\
\hline Earning Persistence & & $-\mathrm{CV}$ & $13.92[0.003]$ & $3.88[0.024\}$ \\
\hline
\end{tabular}

Source: Authors Computation, 2020. Note: $-\mathrm{CV}=$ without control variable, $+\mathrm{CV}=$ with control variable.

The results of the Breusch and Pagan Lagrangian multiplier test and Hausman test in Table 4 for all the models show significant results at $5 \%$ levels. These indicate that panel effect prevail and as a matter of fact, fixed effect models are found to be the preferred or appropriate model for this study.

\subsection{Result}

Table 5. Financial Reporting Quality and Human Resource Accounting.

\begin{tabular}{|c|c|c|}
\hline \multirow{2}{*}{ Variable } & \multicolumn{2}{|c|}{ Fixed Effect (FE) Cluster-robust Standard Error } \\
\hline & Coeff. (t-stat.) [P-value] & Coeff. (t-stat.) [P-value] \\
\hline Wages and Salaries (WAS) & $-0.058 * * *(-5.179)[0.001]$ & $-0.058 * * *(-5.314)[0.000]$ \\
\hline Pension and Retirement Benefits (PRB) & $-0.052 * *(-3.166)[0.011]$ & $-0.052 * *(-3.186)[0.011]$ \\
\hline Number of Employees (NE) & $0.007(1.079)[0.309]$ & $0.006(0.743)[0.476]$ \\
\hline Firm Leverage (LEV) & & $-0.006(-0.174)[0.866]$ \\
\hline Constant & $1.472 * * *(15.279)[0.000]$ & $1.485 * * *(30.038)[0.000]$ \\
\hline Observations & 90 & 90 \\
\hline R-squared & 0.346 & 0.346 \\
\hline Adj. R-squared & 0.315 & 0.323 \\
\hline F-Stats. $[\mathrm{P}$ - value $]$ & $65.13[0.000]$ & $217.6[0.000]$ \\
\hline Prob $>$ F & 0.000 & 0.000 \\
\hline Heteroskedasticity tests [P - value $]$ & $1047.66[0.000]$ & $1047.66[0.000]$ \\
\hline Pesaran's CD test [P - value] & $-2.013[1.956]$ & $-2.026[1.957]$ \\
\hline Autocorrelation test [P - value] & $193.061[0.000]$ & $179.321[0.000]$ \\
\hline
\end{tabular}

Source: Authors Computation, 2020. Note: $* * *$ denotes $\mathrm{p}<0.01$ and $* *$ denotes $\mathrm{p}<0.05$.

In the middle column of Table 5, a quick check on Fstatistic $[\mathrm{P}-$ value $]$ of the selected model which is $65.13[\mathrm{P}-$ value] show that the model is statistically significant at $5 \%$ level. This also means that the joint effect of Wages and Salaries (WAS), Pension and Retirement Benefits (PRB) and Number of Employees (NE) on Earnings Quality (EQT) is statistically significant. Also, the Adjusted $\mathrm{R}^{2}$ value which is 0.315 shows that Human Resource Accounting indicators jointly cause about $31.5 \%$ of variations in Earnings Quality (EQT). Nevertheless, the separate effect of the Human Resource Accounting indicators as measured beta $(\beta)$ values reveals that the coefficient of Wages and Salaries (WAS) is negative and statistically significant at $5 \%$ level $[\beta=-0.058 ; \mathrm{P}$ - value $=0.001]$. This indicates that the effect of Wages and Salaries (WAS) on Earnings Quality (EQT) during the period of the study is significant. Also, another determinant of
Earnings Quality (EQT) as revealed by the result in the middle column of Table 5 is Pension and Retirement Benefits (PRB). The coefficient of PRB is found to be negative and statistically significant at $5 \%$ level. On the contrary, Number of Employees (NE) is not found to be the determinant of Earnings Quality (EQT) of the listed oil and gas companies in Nigeria durng the period of this study. This is because; the estimated coefficient of the variable is statistically insignificant, though it appears to be positive.

\subsection{Discussion of Findings}

The findings in table one demonstrated that the Human resource accounting influenced financial reporting quality of public quoted oil \& gas companies in Nigeria. This means that investors make quality decisions based on the financial 
information provided by managers (human asset) of oil \& gas companies in Nigeria. This is in line with the findings of the study of [10] who found that financial reporting quality has positive effect on shareholder's value as a result of the contribution of human assets in the organization.

From the findings in table one, it revealed that accounting conservatism also known as the doctrine of prudence, is a policy of anticipating possible future losses but not future gains. This policy tends to understate rather than overstate net assets and net incomes and therefore lead companies to play safe. This means that shareholders as decisions makes are provided with clear financial statements that shows the high level of prudency which takes care of known and anticipated losses. The findings corroborate with the findings of the study of [15] who found that preparation of quality financial statements are done with the help of human asset within the organisation.

The findings in table one demonstrated that quality of reports is imperative to the shareholders value creation. This in collaboration with the findings of the study of [18] who found that companies that companies need to disclose quality report to show accountability and transparency that are required by stakeholders and policies making boards. The findings again demonstrated that the relevance of financial information has a positive and significant effect on shareholders' value creation in oil and gas companies in Nigeria. This indicates that shareholders still insists on relevance of financial information because it may be hard for them to make effective decisions regarding the future periods and companies forecasts for the coming years.

This finding in table one showed that pension \& retirement benefit has a positive and significant effect on the financial reporting quality of oil \& gas companies in Nigeria. This shows that information provided to shareholders need to be adequate, relevant $\&$ reliable, the inclusion of pension and retirement benefits in the financial statement of oil \& gas companies show that the information is not on a yearly basis on the report and so it is difficult for the shareholders to measure the trends in the financial statement for the last five years and that is the reason why the relevant ratios are not mostly attached to the financial reports.

The findings indicated that human resource accounting has a positive and significant effect on financial reporting quality of oil \& gas companies in Nigeria. This shows that whatever could harm employees interests is avoided and recognized on time before their firm could not be able to provide to them what they are entitled to. This is in line with findings of the study of [8] who found that provisions of salary, wages and related benefits should be procured on time in order to enhance employee's performance. The study found that employee salary and other related benefits should be provided on time and that employment stability depends on obeying employee welfares and rights rather than only considering shareholder's interest.

\subsection{Implication of Findings}

The findings of this study has implications to management of oil and gas companies, regulators, accounting practice, employees, government agency, investors and shareholders and researchers. The study has revealed that human resource accounting (wages \& salaries, Pension and retirement benefit and Number of employees) have significant effect on quality of financial reporting of quoted oil and gas companies in Nigeria.

The study revealed to management of oil \& gas companies their level of application human resource accounting and indicated the value created by the human asset is enormous in the oil and gas industry. The findings of the study may help them to agitate for the inclusion of human assets in the financial report due to the immense contribution towards the development of the oil \& gas companies in Nigeria.

The findings informed the policy makers that measures can be taken by regulators in pushing oil\& gas companies to providing quality based information that include human assets as part of the financial report. The inclusion may serve as a way of reporting fairly the enormous contribution of the human asset in oil and gas companies in Nigeria.

Accounting practices in Nigeria are provided with the information from this study that human resource accounting is paramount to the preparation \& presentation of financial reporting that aid the decision making of all businesses, especially in oil and gas companies in Nigeria. Hence, Accountant in practice and academic should embrace the call for inclusion of human asset in financial report.

Government agencies especially PPPRA is provided with information about human assets from oil and gas companies and their contribution to the governmental value creation in terms of preparing adequate and quality financial report in Nigeria capacity to support its social and economic development imperatives and Nigeria. Government agency such as National Emergency Management Agency (NEMA) is provided with the findings about the contribution of human asset in oil \& gas companies in Nigeria. Thus, the findings may help in improving the environmental protection standards in Nigeria.

Stakeholders are provided with the fair position of the financial statement prepared by human asset which help them in making economic and informed decision. Also, enable the stakeholders (employees) to agitate for better working condition such as training and development. The contribution of the human asset in the utilization and management of their funds is paramount to the success of oil and gas companies in Nigeria.

\section{Conclusion and Recommendations}

The study examined the impact of Human Resources Accounting on the quality of financial resource of oil and gas companies in Nigeria. The findings from the study provide relevant empirical evidence by showing that wages and salaries, pensions and retirement benefits and number of employees have joint effect on accounting conservatism which is statistically significant. On the contrary, the coefficient of number of employees (NE) is found to be 
statistically insignificant through negative, thus it is not a determinant of account conservation (ACC) of the listed oil and gas companies Nigeria. The quality of financial reporting is enhanced by human asset. The quality of financial statement is made up of faithful representation, verifiability, earnings management/timely loss recognition and accounting conservatism, while the measurement of the financial reporting quality are enhanced by earnings predictability and earnings quality. The stakeholder's value creation is positively linked to timelines, verifiability, earnings management and information disclosure while is negatively affected by relevance of financial information and earnings predictability and the study concludes that stakeholders value creation is positively predicted by these qualitative characteristics of financial statement.

Based on the aforementioned findings of the study, the following recommendations were made to different bodies in charge of financial reporting and management of human resources accounting in general.

i. Board of directors (BOD) of human assets should pay more attention to the relevant of resources accounting as regard the contributions to the quality of financial report in oil and gas companies in Nigeria. This would help in spurring the human assets to give more in terms of the quality of financial report. Management of oil and gas companies should pay more attention on relevance, faithful representation and understandability of their financial reports and provide more information that would help employees to measure and evaluate their performance in accordance to the professional and statutory standard.

ii. Management of oil and gas companies should work hand in hand with government agencies in order to report fairly and that the financial statements should be made relevant and that the contribution of the human assets should be properly reported instead of the traditional system of reporting

iii. Oil and Gas company's management should provide relevant, comparable, understandable, well disclose and timely information and predictable information regarding the social needs of human assets and reveal information about their activities towards the quality of financial report.

\section{References}

[1] Abubakar, S. (2015). A critique of the concept of Human Resources Accounting. Nigerian journalof Accounting\& finance, 2 (1), 93-105.

[2] Abeysekera, I. 2008. Intellectualcapital disclosure trends: Singapore and Sri Lanka. Journalof Intellectual Capital, 9 (4), 723-737.

[3] Akintoye, I. R. (2012). The Relevance of Human Resource Accounting to EffectiveFinancial Reporting. International of BusinessManagement \& Economic Research, 3 (4), 566-572.

[4] Alkali, Y \& Asma, N. (2015). The vlue Relevance of
Accounting Disclosure among Nigeria Financial Institutions after the IFRS adoption. Nigerian Journal Publication, 4 (3), 79-89.

[5] Aram. J. M. (2015). Human capital disclosure: Evidence from Kurdistan. European Journal of Accounting Auditing and Finance Research, 3 (3), 21-31.

[6] Argandona, A. (2011). Stakeholder theory and value creation. Working Paper, WP 922 University of Nawara, 1-15.

[7] Atkins, P. (2018). Theoretical Evidence of the efficiency of intangible Assets in the quality of financial reporting. International Journal of Scienttific and Research publications $3(8), 91-102$

[8] Bhatti W. \& Zaheer, A. (2014). The role of intellectualcapitalin creating and adding value to organizational performance: A conceptual analysis. The Electronic Journal of knowledge management, 12 (3), 187194.

[9] Brandt, T. \& Konstantinos, G. (2016). Shareholders vs stakeholders' capitalism. Pennsylvania: University of Pennsylvania Law School.

[10] Deegan, C., Rankin, M. \& Tobin, J. (2002). An examinationof the corporate social and environment disclosure of BHP from 1983-1997: A test of legitimacy theory. Accounting, Auditing and Accountability Journal, 15 (3), 312-343.

[11] Eke, G. O (2018). Internal control \& financialperformanceof HospitalityOrganisation inRiver State. EuropeanJournal ofAccounting \& Research, 2 (6), 224-255.

[12] Flamholtz, B., Bullen, K. \&Hua, W. (2015). Human capital disclosures: Evidence from Kurdistan. InternationalJournalof Scientific Research, 5 (6), 44-50.

[13] Galani, D. Alexandrite, A. \&Stavropoulos, A. (2011). The association between the firm characteristics and corporate mandatory disclosure the case of Greece. Worldacademy of Science, Engineering and Technology 53 (1), 156-163.

[14] Gyorgy, M. (2016). Human Resource Accounting \& Measurement of Financial Statements in Nigeria. Journal of Accounting \& Management, 7 (3), 333-394.

[15] Higson, C.(2016). ReportingHuman Capital: Acounting for Human Resources. Journal ofAccounting\& Finance, 8 (10), 330-350.

[16] Jarostia, S. (2016). Internal control \& financial performance of Hospitality Organisation in River State. EuropeanJournal of Accounting \& Research, 5 (12), 324-355.

[17] Klai, E. \& Omri, S. (2011). Human Resource Accounting: An Assessment of the valuation models \& Methods. Nigeria journal of Accounting \& finance, 2 (3), 90-102.

[18] Larsson, D.\& Morling, A. (2015). The casual relationship between Human Capital \& Stock performance. International Journal of Accounting \& finance, 3 (7), 442-556.

[19] Ladegaard, G. \& Casten, M. (2015). Value Creation in knowledge intensive firms. International Journal of Academic Research in Accounting, Finance \& Management Science, 12 (10), 622-623.

[20] Lev, H. (2016). Appraisal of Human Resource Accounting on Profitability \& Corporate Organization. Journal of Economics \& Science, 2 (23), 321-344. 
[21] Lyndon, M. \& Sunday, O. (2018). Environmental Responsibility Reporting \& Financial Performance of Nigerian quoted oil \& gas Companies In Nigeria. European Journal of Business \& Innovation Research, 5 (10), 23-34.

[22] Macerinskiene, I. \& Survilaite, S. (2011). Intellectual Capital as the main factor of Company's value Added. Eauropean journal of Business \& innovation Research, 2 (3), 82-100.

[23] Mahmoud, I. (2017). Financial reporting quality of listed companies in Nigeria: Journal of Scientific in Education Studies \& Social Science development, 3 (18), 332-348.

[24] Martinez, F. (2014). Consequences of Financial Reporting Quality on Corporate Performance Evidenceat the International Level. International Journal of Accounting \& Finances, 4 (3), 444-495.

[25] Mehdi, A \& Mohammed - Ali, B. C (2009). Financial Reporting Gap in Developing Countries: The case study of Iran. Iranian Journal of Accounting, 1 (1), 211-225.

[26] Murthy, V. \& Abeysekera, I (2014). Human capital value creation practices of software \& services exporter firms in India. Journal of Human Resources Costing \& Accounting 11 (2), 84-103.

[27] Muhammed, K. (2017). Impact ofaccountinginformationon financialstatementof listedcompanies in Nigeria. International Journal of Accounting \& Business Management, 13 (7), 832852.

[28] Namazi, M. \& Raezei, H. (2012). The effect of inflation rates on the earnings quity o the compnies listed on Tehran Stock Exchange (TSE). Journal of empiricl research in accounting 2 (5), 67-91.

[29] Nwaiwu, J. N. \& Aliyu, A. S. (2018). Intellectual Capital reporting \& measures of Financial \& performance of Company in Nigeria. Journal of Accounting Research \& Financial Management, 13 (2), 421-455.

[30] Nyor, T. (2013), Financial ReportingQuality of Nigeriafirms: Users' perception. International Journal of Business and Social Science, 4 (13), 273-279.

[31] Nyor, T. (2016), Financial Reporting quality of nigerian forms, international journal of business and social science.
[32] Olaleke, Foluso \& Olamide, (2018). An empirical study of HRA disclosure on financial perfomance on selected firms in nigeria. International Journal of Advancement in Research and Technology, 18 (10), 400-435.

[33] Pivac, S. Vuko, T. \& Ular, M. (2017). Analysis of annual report disclosure quality for listed companies in transition countries. Economic Research- Ekonomska Instrazivanja, 721-731.

[34] Sani, U. \& Usman, M. (2018). Impact Of Financial Performance On Human Capital Efficiency of Nigerian quoted oil \& gas company. International Journal For Innovative Research In Multidisciplinary Field, 3 (2), 86-112.

[35] Shehu, U. H. (2013). Financial reporting quality, does monitoring characteristics matter? An empirical analysis of Ngerian Manufacturing sector. The Business \& Management Review, 3 (2), 147-161.

[36] Shipper, K. \& Vincent, L. (2018). Earnings Quality in Corporate environment. Journal of Accounting \& finances, 8 (13), 62-84.

[37] Siriyama, H. \& Norah, A. (2017). Financial Reporting Quality: A Literature Review. International Journal of Accounting \& Finances, 6 (12), 200-222.

[38] ThankGod, C. (2015). Nigerian quoted oil \& gascompany Accounting in the Nigerian Petroleum Industry. Nigerian Journal of Accounting \& Finances, 6 (7) 2222-2847.

[39] Uwalomwa, U. \& Olamide, O. (2013). An evaluation of stakeholders and accounting teachers perception of corporate social and environmental disclosure practice in Nigeria. An InternationalMultidisciplinary Journal, Ethiopia, 7 (1), 352365 .

[40] Youssef, W. (2017). The Effect ofEarningsManagement \& Disclosure on Information Asymmetry. International journal of Accounting \& Finances, 4 (18), 10-28.

[41] Yiwei, D. Kristian, H., Wayne, B. T. \& Youli, Z. (2018). Blockholder exit threats and financial reporting quality. Contemporary Accounting Research Banner, 23 (2), 68-75. 